Acta vet. scand. $1969,10,44-47$.

From the Department of Animal Genetics, Nutrition and Hygiene, Royal Veterinary College, and the Department of Forest Zoology, Royal College of Forestry, Stockholm, Sweden.

\title{
A NOTE ON THE SOMATIC Y CHROMOSOME OF REINDEER (RANGIFER TARANDUS L.)*)
}

\author{
By \\ Ingemar Gustavsson and Carl Olov Sundt
}

Recently a report on the reindeer chromosomes was published (Nes et al. 1965). The chromosome complement was described as consisting of $\mathbf{7 0}$ autosomes and a sex chromosome set of the XY-type. All autosomes were acrocentric except one pair which was submetacentric. The $\mathrm{X}$ was found to be submetacentric and also the largest chromosome of the complement. The $\mathrm{Y}$ was characterized as being the smallest acrocentric chromosome, and the authors stated that the $Y$ chromosome could only occasionally be distinguished from the autosomes by its shorter length.

In our studies of the same species we have found a quite different appearance concerning the $\mathrm{Y}$ chromosome.

\section{MATERIAL AND METHODS}

Tissues of lung and muscle were collected at slaughter from 47 animals, 31 males and 16 females, originating from different geographical areas and representing both ecological types described by Nilsson (1847) (Table 1). Tissue cultures were set up according to the method described by Basrur et al. (1963); the cultured cells were harvested about ten days later and treated in the conventional ways previously described by Gustavsson (1965).

*) We wish to thank the veterinarians Sten Söderberg, Sixten Dahlqvist and Henry Holm for kindly supplying us with material for these studies. - This work has been supported by the Swedish Natural Science Research Council. 


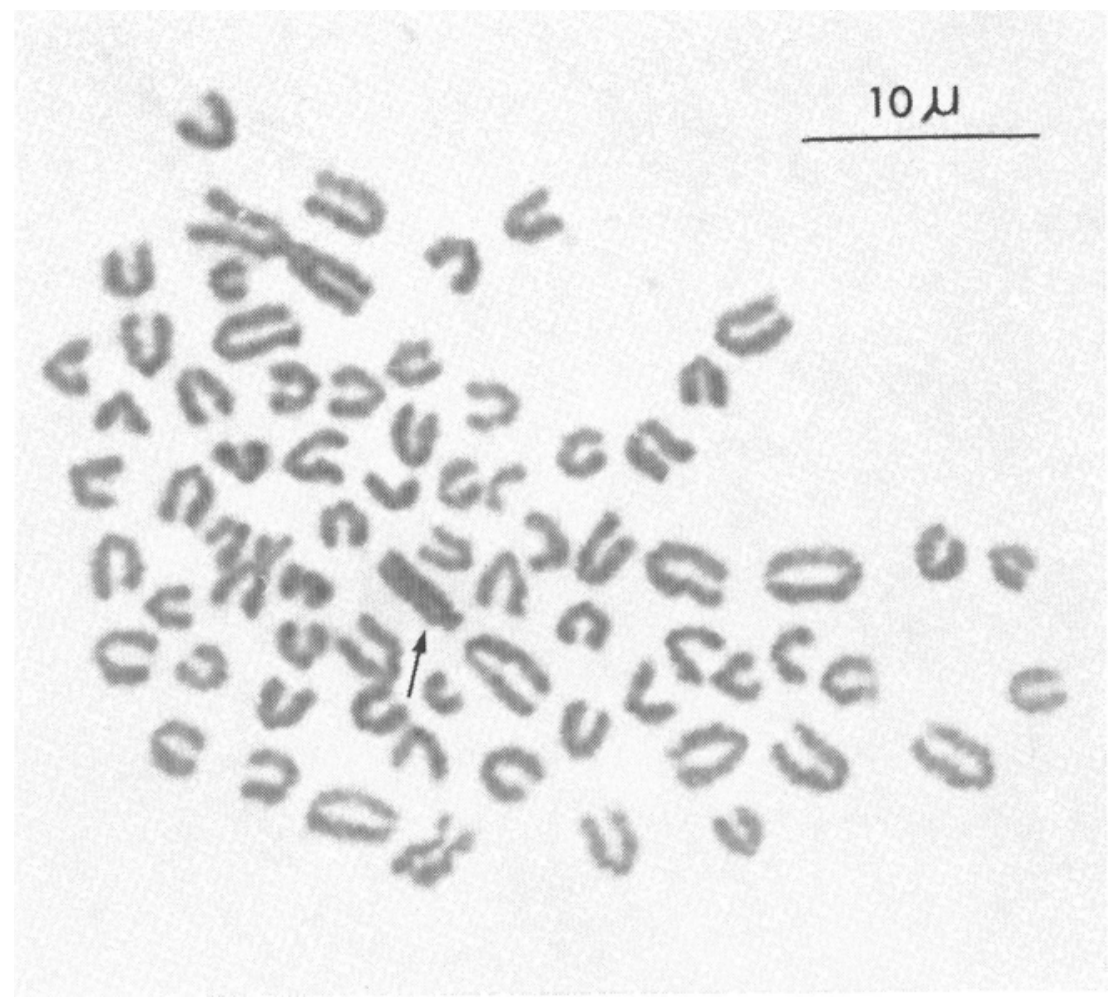

F igu re 1. Somatic metaphase figure from lung of a male reindeer of the forest ecotype. The arrow points to the $\mathrm{Y}$ chromosome. 


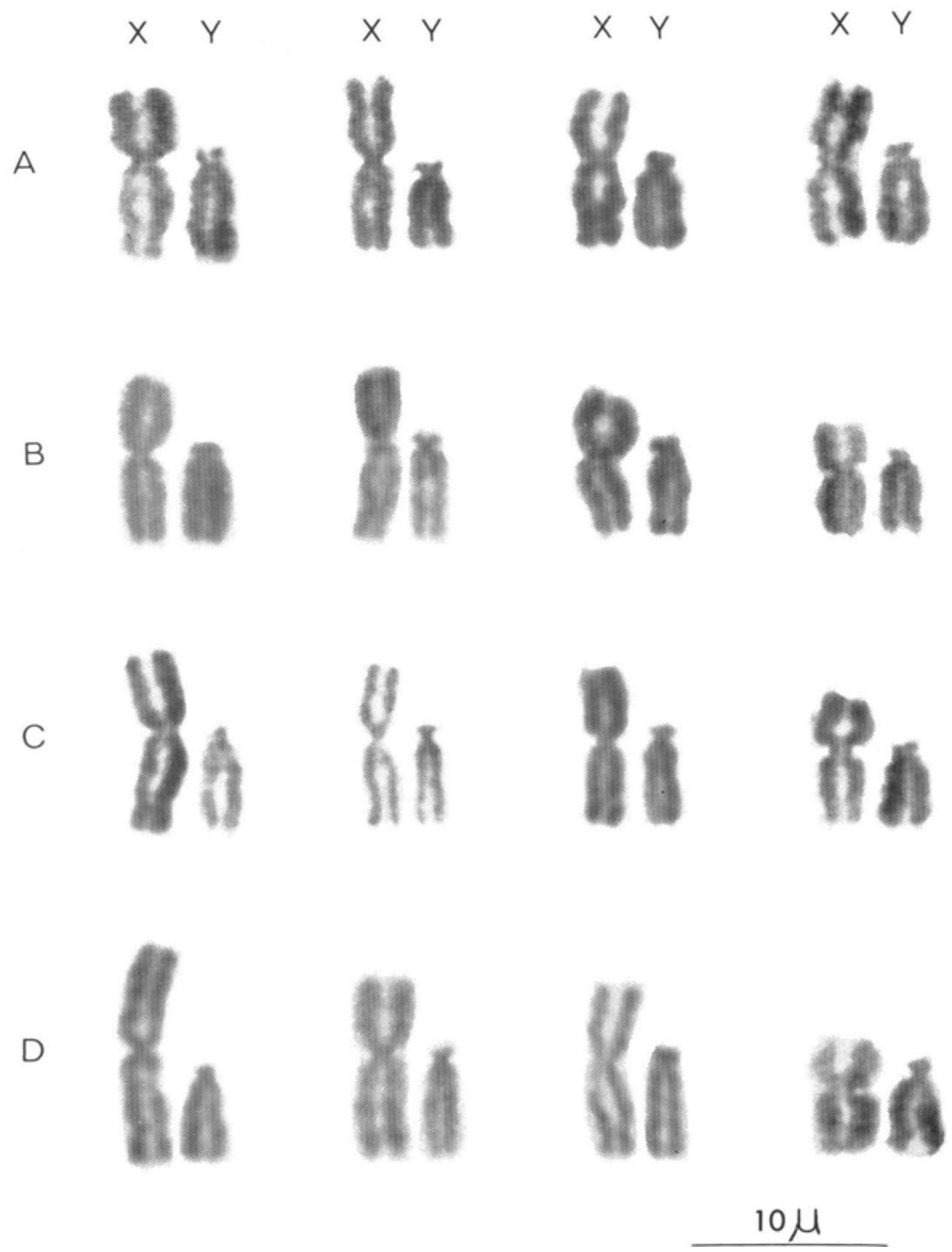

Fig u r e 2. The sex chromosomes from cells of four male reindeer representing the four populations studied. A: Luleå; B: Norsjö; C: Storuman; D: Arvidsjaur. 
T a ble 1. Geographical origin, number, sex, tissue and ecological type of reindeer studied.

\begin{tabular}{lccll}
\hline $\begin{array}{l}\text { Geographical } \\
\text { origin }\end{array}$ & $\begin{array}{c}\text { Number of animals } \\
\text { investigated }\end{array}$ & Tissue & $\begin{array}{c}\text { Ecological } \\
\text { type }\end{array}$ \\
\cline { 2 - 3 } & $\sigma^{\pi}$ & 9 & & \\
\hline Luleå & 9 & 11 & lung & forest \\
Norsjö & 5 & & lung & forest \\
Storuman & 5 & 3 & lung & forest \\
Arvidsjaur & 12 & 2 & muscle & mountain \\
\hline
\end{tabular}

\section{RESULTS AND DISCUSSION}

The female karyotype was of the same type as that described by Nes et al. (1965). The $\mathrm{X}$ chromosome is remarkably long and must be considered as belonging to another type than the original one (Ohno et al. 1964). Furthermore a very large $\mathrm{Y}$ chromosome was found in all males studied (Fig. 1). It is one of the largest chromosomes of the complement and measures about $5 \mu$ in most metaphases treated with colchicine. It can be described as acrocentric according to the nomenclature used above, but in all males studied one very small arm can be seen in addition to the long arm (Fig. 2). This feature makes it possible to distinguish this chromosome from the autosomes. Further, it often appears heteropycnotic, and the metaphase chromatid splitting is not as clear as in other chromosomes. Additionally, it has an allocyclic behaviour within the individual. Of course the distinction is based only on size and morphology, but it is most probably the male determining chromosome as the female reindeer lacks such a chromosome. Meiotic and autoradiographic studies also support this conclusion (Fraccaro et al. 1968). A large $\mathrm{Y}$ chromosome has previously also been observed by Makino (1952) in another species of reindeer (Rangifer phylarchus). Other species of deer hitherto studied by us (Gustavsson \& Sundt, unpublished) have shown a small $Y$ chromosome and an $X$ chromosome of the original type (Ohno et al.) measuring about $5 \%$ of the female haploid complement.

The deviation in our observations from those of Nes et al. is very interesting and may have different explanations. First of course we have to consider the possibility of incorrect identification. Such difficulties have for a long time existed in several mammals. Secondly it is possible that we are dealing with a case 
of intraspecific polymorphism. From the observations of this work it is possible to conclude that the $\mathrm{Y}$ chromosome consists mainly of heterochromatin. As the $\mathrm{X}$ and $\mathrm{Y}$ chromosomes seem to be paired end-to-end during meiosis (Fraccaro et al.) there is but little homology between the $X$ and the $Y$. Due to this and the heterochromatic nature of the $\mathrm{Y}$ it is reasonable to assume the existence of a variability in size of the $Y$ chromosomes in the population.

Polymorphic $\mathbf{Y}$ chromosomes have earlier been observed in several mammals. In one non-inbred and two inbred colonies of Wistar rats two distinct types of $\mathrm{Y}$ according to size were observed (Hungerford \& Nowell 1963). Lehman et al. (1963) found two different forms of the $\mathrm{Y}$ chromosome in the Syrian hamster (Mesocricetus auratus) and in the discussion the authors propose the existence of several types of $\mathrm{Y}$ chromosomes in the studied species according to size and morphology. In three different strains of laboratory mouse a Y chromosome with a small but distinct chromosome arm which makes this chromosome easy to identify was recently observed (Ford 1965; Nowell 1965; Balaban et al. 1968).

Thus several facts indicate the existence of a polymorphic $\mathrm{Y}$ chromosome system in reindeer. This must be investigated, however, in further works.

\section{REFERENCES}

Balaban, G., D. A. Hungerford \& D. Steinmuller: A distinctive Y chromosome in another strain of laboraîory mouse (NZB/B 1). Mammalian Chromosome Newsletter 1968, no. 9, 5-6.

Basrur, P. K., V. R. Basrur \& J. P. W. Gilman: A simple method for short term cultures from small biopsies. Exp. Cell Res. 1963, 30, $229-232$.

Ford, C. E.: The murine Y chromosome as a marker. Transplantation $1965,4,333-335$.

Fraccaro, M., I. Gustavsson, Maj Hultén, J. Lindsten \& L. Tiepolo: Chronology of DNA replication in the sex chromosomes of the reindeer (Rangifer tarandus L.). Cytogenetics 1968, 7, 196-211.

Gustavsson, I.: Somatic chromosomes of the cat. Acta vet. scand. 1965, $6,274-285$.

Hungerford, D. A. \& P. C. Nowell: Sex chromosome polymorphism and the normal karyotype in three strains of the laboratory rat. J. Morph. 1963, 113, 275-286.

Lehman, J. M., I. Macpherson \& P. S. Moorhead: Karyotype of the Syrian hamster. J. nat. Cancer Inst. 1963, 31, 639-650. 
Makino, S.: A contribution to the study of the chromosomes in some Asiatic mammals. Cytologia (Tokyo) 1952, 16, 288-301.

Nes, N., J. Amrud \& O. B. Tфndevold: Kromosomstudier hos rein (Rangifer tarandus). (Chromosome studies in reindeer (Rangifer tarandus)). Nord. Vet.-Med. 1965, 17, 589-593.

Nilsson, S.: Skandinavisk fauna I. Däggdjuren. (Scandinavian fauna I. Mammals). C. W. K. Gleerup, Lund. 1847.

Nowell, $P$. C.: An unusual Y chromosome in Swiss mice. Mammalian Chromosome Newsletter 1965, no. 17, 73.

Ohno, S., W. Beçak \& M. L. Beçak: X-autosome ratio and the behaviour pattern of individual X-chromosomes in placental mammals. Chromosoma (Berl.) 1964, 15, 14-30.

\section{SUMMARY}

The chromosome complement of the reindeer (Rangifer tarandus L.) with special reference to the $Y$ chromosome has been described. Deviating from earlier observations the $\mathrm{Y}$ was found to be one of the largest chromosomes in the complement and distinguishable from the autosomes. Various possible reasons for the deviating results are discussed.

\section{ZUSAMMENFASSUNG}

Eine Aufzeichnung über das somatische Y-Chromosom des Renntieres (Rangifer tarandus L.).

Das Chromosomenkomplement des Renntieres mit besonderer Rücksicht auf das Y-Chromosom ist beschrieben worden. Abweichend von früheren Observationen zeigte sich das Y-Chromosom eines von den grössten Chromosomen des Komplements zu sein und unterscheidbar von den Autosomen. Verschiedene mögliche Ursachen der abweichenden Resultate werden diskutiert.

\section{SAMMANFATTNING}

En anteckning om den somatiska Y-kromosomen hos ren (Rangifer tarandus L.).

Kromosomkomplementet hos ren (Rangifer tarandus L.) med speciell hänsyn till $\mathrm{Y}$ kromosomen har beskrivits. Avvikande från tidigare observationer befanns $Y$ vara en av de största kromosomerna i komplementet och möjlig att skilja från autosomerna. Olika möjliga orsaker till de avvikande resultaten diskuteras.

(Received July 31, 1968). 